\title{
Tangsi-Tangsi Kolonial dan Tahanan Perempuan di Sumatera Barat
}

\author{
Dedi Arsa \\ IAIN Bukittinggi, Indonesia \\ E-mail: deddyarsya1987@gmail.com \\ Lukmanul Hakim \\ UIN Imam Bonjol Padang, Indonesia \\ E-mail: 1ukmanulhakim@uinib.ac.id
}

\begin{abstract}
This article studies the women's ward and the Dutch colonial regime to the female prisoners in West Sumatera. (Sumatra's Westkust). As the historiography works it use a modern histories arrangements: heuristic, internal - external critics; Interpretation classification; explanation in historiography. It uses female history approach, studying the the womens' position under the patriarchal. This study reveals that: The prisons had been built since 17th Century, it was began at Padang to the higher land as the Nederland Political Power became more powerfull; 2) It was recorded that was no women's ward at that time, there was only a special room among the men's for the women before they were sent to Java, all of the personels were males; 3) The inavailability of women's ward and the female personels make the females prisoner became more badly suffer as their punishment had been doublelized especially for those who were coomited to custom and moral values.
\end{abstract}

Keywords: Women's ward; Prison / detention; Colonialism; Sumatera's Westkust

\begin{abstract}
Abstrak
Artikel ini menelaah keberadaan bangsal khusus perempuan dan perlakukan kekuasaan kolonial Belanda terhadap perempuan-perempuan dalam penjara-penjara kolonial yang ada di Sumatra Barat (Sumatra's Westkust). Artikel ini merupakan karya historiografi yang penyusunannya menggunakan metode penyusunan yang dikenal pada umumnya dalam metode penyusunan sejarah modern: heuristik, kritik intern-ekstern; klasifikasi-interpretasi; dan ekplanasi dalam bentuk historiografi. Pendekatan yang dipakai adalah pendekatan sejarah perempuan yang menelaah posisi perempuan di bawah kekuasaan patriarkis-kolonial. Dari artikel ini dapatkan: 1). Penjara-penjara kolonial telah hadir di Sumatra Barat sejak abad ke-17, bermula di Padang dan jejaring itu semakin melebar ke dataran tinggi Minangkabau seiring menguatnya kekuasaan politik kolonial di abad-abad setelah itu; 2) Namun tidak satu pun penjara-penjara koloial yang ada di Sumatra Barat itu menyediakan bangsal khusus bagi perempuan, selain hanya ada kamar titipan di antara sel-sel laki-laki sebelum si terhukum-perempuan dikirim ke penjara khusus perempuan di Jawa; semua petugas dari lapisah paling bawah hingga yang teratas juga adalah laki-laki; 3) Ketiadaan bangsal khusus perempuan dan petugas perempuan telah memberi hukuman yang berlipat ganda bagi seorang tahanan perempuan,
\end{abstract}


terutama tahanan perempuan Minangkabau yang biasa menjunjung adat dan nilai moral: hukuman badan karena terkurung terali dan tembok \& hukuman psikologis sekaligus karena harus berhadapan dengan petugas-petugas yang semuanya laki-laki

Kata kunci: bangsal perempuan, penjara/tangsi, kolonialisme, Sumatera's Westkust

\section{PENDAHULUAN}

Tangsi sesungguhnya berarti basecamp atau barak tentara (Tim Badan Pengembangan dan Pembinaan Bahasa). Namun dalam masyarakat Sumatera Barat, kata ini juga digunakan untuk penjara. Ini disebabkan karena tangsi (militer) dalam sejarah kolonial di daerah ini juga pernah digunakan untuk memenjarakan para terhukum karena kekurangan bangunan penjara. (Hadler, 2003; Rahman, 2019; Risa, 2019; Romi, 2019). Dalam konsepsi kolonial, penjara dikonsepsikan sebagai ge houden, tempat penahanan untuk membatasi kebebasan si terhukum sebagai reaksi atas pelanggaran yang telah diperbuatnya. Hingga kini, dalam masyarakat Sumatera Barat, penjara dikenal dalam berbagai terminologi yang beberapa di antaranya merujuk pada pengalaman mereka terhadap kolonialisme: bui (Spierenburg, 1991), rumah tahanan (huisgevangenis), gaduang panjaro [gedung penjara] atau pinjaro (Hasselt, 1882; Van Hasselt, 1882) dan kadang-kadang dinamakan 'kandang si tumbin'. Kata 'tumbin' sendiri dalam khasanah Bahasa Minang berarti kambing. Penjara dengan begitu dianalogikan sebagai kandang kambing, dimana penghuninya makan, tidur dan buang air besar dilakukan di kandang tersebut.

Penjara di Sumatera Barat mulamula hadir di Padang (kota utama kolonial di pantai barat Sumatera) pada awal abad ke-19. Lalu terus berkembang hingga menjalar sampai ke dataran tinggi Minangkabau pada abad berikutnya dan terus melebar hingga melingkupi nyaris seluruh daerah tersebut hingga akhir kekuasaan kolonial. (Arsa, 2013).

Jika membahas penjara, apalagi pada periode kolonial, narasi yang mengemuka nyaris selalu tentang laki-laki. Sejarah perempuan dalam penjara kolonial ini hampir-hampir belum mendapat perhatian yang memadai. Apalagi untuk wilayah kajian Sumatera Barat (Sumatera's Westkust dalam penyebutan zaman kolonial). Padahal di daerah ini, tempat etnik Minangkabau yang matrilineal banyak bermukim, perempuan tampak memainkan fungsinya yang berarti sebagai pusat pergerakan kebangsawanan melawan penjajahan, sehingga banyak di antara mereka yang dipenjarakan (Arsa, 2017).

Artikel ini menelaah kehidupan perempuan dalam penjara-penjara di Sumatera's Westkust wilayah yang kini bernama Sumatera Barat, wilayah utama etnis Minangkabau (dalam artikel ini penggunaan ketiganya akan saling dipertukarkan tetapi merujuk kepada maksud yang sama). Fokus artikel ini adalah melihat keberadaan bangsal khusus perempuan dan perlakuan terhadap perempuan dalam penjara-penjara yang ada di Sumatera Barat.

\section{METODE PENELITIAN}

Metode yang digunakan dalam penyusunan hasil penelitian ini adalah metode penyusunan yang dikenal pada umumnya dalam penyusunan sejarah modern, yaitu meliputi empat tahapan: heuristik, berupa pengumpulan 
bahan/sumber; kritik sumber berupa kritik intern-ekstern; interpretasi berupa pengklasifikasian data-data dan mencari hukum kausalnya; dan eksplanasi dalam bentuk historiografi. (Gilbert, 1953, 1953; Kartodirdjo, 1993; Kuntowijoyo, 2003). Tulisan ini sedapat mungkin melacak sumber-sumber tua dari yang tersedia dan dapat dilacak, semisal beberapa surat kabar dan berkala kolonial, juga arsip dan dokumen resmi pemerintah jajahan.

\section{PEMBAHASAN}

\section{Jejaring Tangsi di Sumatera's Westkust}

Cikal-bakal penjara kolonial di Sumatera Barat adalah penjara di benteng serikat dagang Hindia Timur (VOC) di Padang pada abad ke-17 (Kielstra, 1980). Pada periode Hindia Belanda yang dimulai sejak awal abad ke-19, penjara semakin ditegaskan fungsinya di kawasan ini seiring terlibatnya Belanda dalam Perang Padri. Lalu piranti hukum ini terus berkembang hingga menjalar sampai ke dataran tinggi Minangkabau dan terus melebar hingga melingkupi nyaris seluruh daerah tersebut hingga akhir kekuasaan kolonial pada paro pertama abad ke-20 (Arsa, 2017).

Nahuijs, seorang Belanda berpangkat kolonel, mengunjungi Padang pada tahun 1824. Nahuijs mencatatkan tentang rumah-penjara pemerintah kolonial di kota itu yang sangat kecil (het gouvernements gevangan-huis zoo weinig). Akibatnya, ketika malam, para penjahat yang dipenjarakan di situ harus dirantai sebagai jaminan agar mereka tidak melarikan diri. Penjara kecil ini juga harus dijaga oleh beberapa orang polisi, yang menjaga para tahanan dengan ketat, untuk tujuan yang sama (Nahuijs, MDCCCXXVI).

Di awal-awal kehadirannnya di Padang, pemerintah kolonial Belanda disibukkan oleh keikut-sertaannya dalam Perang Padri. Kota ini hampir-hampir terabaikan dan belum tersentuh perbaikan sejak diserahkan ke tangan Belanda kembali dari kekuasaan Inggris. Letnan Kolonel Raaff, penguasa Padang masa itu, dengan giat dan penuh ambisi tengah sibuksibuknya menggempur benteng-benteng Padri di dataran tinggi Minangkabau. Seluruh tenaga dikerahkan untuk menaklukan kawasan tersebut. Nahuijs menilai, Raaff nyaris tidak mampu memberikan perubahan yang berarti bagi wajah kota ini (Nahuijs, MDCCCXXVI).

Kedatangan J.J. de Stuers ke Padang pada periode setelah Raaff barulah membawa angin yang lebih baik bagi kepentingan Padang. Stuers dikirim ke Sumatera Barat pada tahun 1824. Dia menjabat Panglima Militer dan Residen Sumatera Barat yang ke-3. Dia bertugas di wilayah ini ketika upaya melanjutkan penyerangan kepada pihak Padri-seperti yang gencar dilakukan pendahulunyasudah tidak mungkin lagi dilakukan. Belanda tengah berkonsentrasi memadamkan pemberontakan Pangeran Diponegoro di Jawa. Perang Jawa telah menyedot bukan hanya kas Belanda tetapi juga konsentrasi pasukan, sehingga prajuritprajurit tempur dipindahkan ke sana dalam jumlah besar. Dalam kondisi terjepit seperti itu, Stuers dengan cerdik berhasil membujuk kaum Padri untuk beberapa kali menyepakati gencatan senjata (Peter Carey, 2008). Pada masa gencatan senjata itulah Stuers memanfaatkan kesempatan untuk beberapa keperluan penting mengokohkan kehadiran Belanda di kawasan itu. Diantaranya, Stuers untuk pertama kali memungsikan pemakaian dubalangdubalang Minangkabau dalam menghadapi kaum Padri (Asnan, 2003).

Sementara gebrakan Stuers yang langsung berimbas kepada Padang pada 
saat itu adalah ia berhasil memperbaharui wajah kota dengan membangun fasilitasfasilitas publik secara lebih giat. Dalam catatannya, Stuers menulis, bahwa pada tahun 1826, dua tahun setelah dia menjabat residen, Padang tengah sibuk memoles diri. Banyak gedung-gedung baru didirikan. Balai kota, kantor pajak, gudang mesiu, gedung pabean, dan perbaikan gereja baru saja selesai didirikan dalam kondisi yang cukup baik. Bersama bangunan-bangunan publik itu, penjara juga didirikan kembali dengan batu (J. J. Stuers, 1849).

Bangunan penjara yang dibangun pada masa Stuers ini terletak di tepi sisi utara Muara Batang Arau. Kompleks penjara dikelilingi oleh tembok yang tinggi, dimana pada bagian depannya terdapat gerbang yang besar dengan satu daun pintu. Di dalam komplek penjara terdapat dua bangunan besar yang berfungsi sebagai bangsal tahanan: satu untuk tahanan biasa dan satu lagi untuk tahanan rantai (dwangarbeid). Sebuah bangsal masingmasing memiliki dua jendela. Di tengahtengah kompleks penjara itu juga terdapat sebuah menara pengintai (J. J. de Stuers, 1849). Sementara tempat kerja (werkplat) terletak di depan penjara. Di halaman depan penjara itu juga terdapat dua bangunan lain yang diperkirakan adalah tempat menginap para penjaga dan petugas penjara. Di depan salah satu bangunan tumbuh sebatang pohon kelapa yang tinggi dan lebat buahnya. Kompleks penjara itu secara umum di kelilingi pohon-pohon yang didominasi pohon kelapa di sekitarnya (J. J. de Stuers, 1849).

Sekalipun sudah dibangun penjara yang lebih luas, namun penjara tersebut, menurut Stuers, tidak mampu menampung jumlah tahanan. Penjara itu, tidak berapa lama setelah dibangun, segera dipenuhi para tahanan, sehingga harus digunakan blokblok tangsi militer sebagai tempat penahanan lain. (J.J. de Stuers, 1849). Dapat dimaklumi mengingat Penjara Padang tidak saja menampung tahanan yang terkait Perang Padri yang tengah berlangsung di pedalaman Minangkabau, tetapi tahanan di pesisir bagian Selatan dan Utara Pantai Barat Sumatera juga dikirim ke Padang. Stuers misalnya mencatatkan, anak seorang kepala desa di Bengkulu yang tertangkap mencuri kerbau, penahanannya juga dikirim ke Penjara Padang. Begitu juga dengan seorang laki-laki asal Pariaman, Tuman, yang menyerang opas, juga dikirim dan dipenjarakan di Penjara Padang (J.J. de Stuers, 1849).

Bangunan penjara yang kecil itu tidak bisa menampung jumlah tahanan dalam kapasitas yang besar akibat gangguan keamanan terus merebak di Sumatera Barat. Di samping itu, overload penjara ini juga berkemungkinan besar adalah akibat dari Perang Jawa: tahanan dalam Perang Diponegoro kebanyakan dikirim ke penjara-penjara di luar Jawa, (Peter Carey, 2008). termasuk ke Sumatera Barat. Atas dasar kepenuhan penghuni inilah, pada tahun 1845, Penjara Padang diperbesar oleh pemerintah kolonial. Dirk Woortman, seorang opsir Belanda yang ditugaskan di Padang, dalam suratnya bertanggal 20 Juli 1845 mencatatkan, bahwa ketika ia mengunjungi Padang, kota itu tengah sibuk membangun penjara baru. Kuli-kuli paksa ( $d$ wangarbeiders) dari Jawa didatangkan untuk bekerja, mereka adalah orang rantai-tahanan kriminal karena kejahatan berat. Bangunan penjara yang dibangun itu seluruhnya terbuat dari batu. (Wilsen, 1869). Setahun kemudian, pada akhir 1846, pembangunan penjara baru tersebut dirampungkan pengerjaannya.

Kompleks penjara baru itu, dalam laporan pemerintah Belanda, memiliki panjang 75 meter dan lebar 30 meter, dengan tinggi 5 meter. Kompleks penjara 
itu dibagi dalam dua koridor. Koridor pertama merupakan koridor untuk menampung para tahanan dengan rantai yang dikirim dari luar daerah Sumatera's Westkust. Sementara koridor kedua adalah koridor untuk menampung para tahanan dari daerah Sumatera Barat sendiri. Kompleks penjara seluas itu, kata laporan yang sama, dapat menampung 400 narapidana (Van Asska, 1859).

Konstruksi penjara tersebut pada periode ini berbentuk tapal kuda (Andri, n.d., 1885). Menurut Hesri Setiawan, jika konstruksi penjara model tapal kuda ini, di tengah bangsal-bangsal bangunan penjara yang melengkung seperti letter $U$ itu, biasanya terdapat lapangan yang cukup luas yang biasanya digunakan untuk apel besar para tahanan. Tembok tinggi mengelilingi bangsal-bangsal itu. Kantor administrasi, ruang pemeriksaan, dapur, dan gudang, terletak berderet-deret di depan pada lingkaran tapal kuda, sistem konstruksi seperti ini biasanya tidak memperbolehkan tahanan bicara satu sama lain, apalagi bergurau sampai menimbulkan gelaktawa.(Krisnadi, 2001; Setiawan, 2016).

Berdasarkan konstruksi seperti dijelaskan di atas itu, Kolonial Verslag tahun 1855 dan 1856 melaporkan bahwa, seperti dikutip C. J. van Asska, Penjara Padang adalah penjara paling layak dan memadai untuk seluruh penjara di Hindia Belanda. Kelayakannya disejajarkan dengan penjara untuk orang Eropa yaitu Penjara Willem I di Weltevreden. Kelayakan itu diukur dari struktur konstruksi penjara itu sendiri: ruang-ruang penahanan yang tersedia (kamar yang tersedia untuk tahanan pribumi dan Eropa), ruang untuk bezoek, dan sistem manajerial atau pengelolaannya (Van Asska, 1859).

Pada akhir abad ke-19, dibangun lagi penjara di Padang. Belum dapat dipastikan, apakah ini renovasi penjara lama atau pembangunan penjara baru. Pembangunan penjara baru ini, bisa jadi dikarenakan daya tampung tidak memadai pada penjara sebelumnya. Tidak didapat sumber yang lebih baik untuk menjelaskan proses pembangunan penjara pada kurun waktu ini. Laporan tahun 1894 hanya menyebutkan bahwa, penjara yang baru dibangun itu dapat menampung 600 tahanan, satu setengah kali lipat lebih banyak dari penjara lama (R. A. van Sandick \& J. E. de Meyier, 1894). Orangorang hukuman berat (strapan dalam pengucapan pribumi) masih dipasok ke penjara ini, yang pada akhir abad ke-19 itu banyak yang ditugas-paksakan membantu serdadu Belanda dalam Perang Aceh, atau pembawa artileri dalam menggempur benteng Sisingamangaraja di pedalaman Batak. Di samping itu, mereka juga diarak sebagai pekerja proyek-proyek jalan, pelabuhan Emma Haven dan kereta api, serta pembukaan tambang batubara di Ombilin-Sawahlunto, yang sedang gencar dilakukan pemerintah kolonial pada akhir abad tersebut (Suyono, 2005).

Sementara di dataran tinggi Minangkabau, dua benteng yang terpenting dan termula adalah Fort de Kock (1824) dan Fort van der Capellen (1822) (Najmi, 2013) adalah tangsi tentara dan gudang perbekalan (Radjab, 1964). Tangsi militer inilah yang dalam berbagai kesempatan berfungsi sebagai ruang penahanan. Tawanan-tawanan dari kalangan Padri berkemungkinan ditahan disini sebelum dikirim ke penjara yang lebih memadai di Padang.

Selain Fort de Kock dan Fort van der Capellen, dalam rangkaian upaya penaklukan dataran tinggi Minangkabau pada periode Perang Padri pula kota-kota kolonial yang lebih kecil bermunculan. Padangpanjang dan Solok (Singkarak) 
adalah kota-kota yang bermula sebagai kota-kota militer pada periode yang hampir bersamaan dengan dua kota yang disebutkan sebelumnya. Padangpanjang, misalnya, adalah salah satu pos pertahanan dan sekaligus batu loncatan yang penting bagi Belanda untuk menggempur bentengbenteng Padri di pedalaman. Padangpanjang sebagai daerah yang menghubungkan wilayah pedalaman dan pesisir pantai memang sangat strategis sebagai basis pertahanan. Kaum Padri menguasai kebanyakan daerah di Agam, kawasan yang akan sangat efektif jika dijangkau dari Padangpanjang. Sebagaimana kota benteng pada umumnya, di Padangpanjang terdapat tangsi militer. Tangsi militer adalah bagian yang penting dalam sejarah Padangpanjang pada periode ini. Pada tangsi militer tersebutlah terdapat ruang-ruang pemenjaraan (Arsa, 2017).

Tidak didapatkan keterangan yang lebih memadai bagaimana kondisi persisnya penjara-penjara di kota-kota dataran tinggi Minangkabau pada periode Padri ini. Gambaran yang lebih terang berasal dari pertengahan abad itu, beberapa dasawarsa setelah berakhirnya perang. Menurut keterangan tersebut, pada pertengahan abad ke-19, tidak seperti penjara di Padang yang dipuji-puji, penjara-penjara lain di beberapa kota di dataran tinggi justru, dalam kondisi yang bertolak-belakang. Penjara di Padangpanjang dan Fort de Kock, misalnya, dicatatkan dalam kondisi yang sangat jelek dan memprihatinkan. Dindingnya hanya ditutupi dengan alang-alang, dan banyak sisi bangunannya yang somplak(Van Asska, 1859). Pada tahun 1850, Fort de Kock dan Padangpanjang sesungguhnya telah mengirimkan proposal anggaran ke Gubernur Jenderal di Batavia untuk pembangunan penjara baru (Utrecht, Kemink en Zoon, 1858). Tahun 1857, proposal baru diajukan lagi, (Van Asska,
1859), akan tetapi baru tiga tahun kemudian proposal yang kedua itu mendapat respon dari pemerintah pusat di Batavia, itupun yang disetujui hanya untuk pembangunan penjara di Fort de Kock.

Pada tahun 1860, penjara baru sedang dibangun di Fort de Kock. Pekerjapekerja paksa (yang berasal dari tahanan hukuman berat yang dikirim dari Penjara Padang) didatangkan ke Fort de Kock untuk menyelesaikan pembangunan penjara baru tersebut (Andri, n.d.). Penjara Bukittinggi, sampai abad kemudian, masih tergolong penjara kecil yang terdiri dari belasan kamar dan diperuntukkan hanya bagi tahanan hukuman tiga bulan ke bawah. Kantor kepala penjara terletak di sebelah depan dekat pintu gerbang, yang berjejer dengan bilik-bilik tahanan, dan dapuryang masing-masing dipisahkan oleh ganggang. Penjara itu, catat Maisir, "bagaikan pulau-pulau terpencil di tengah lautan yang terputus hubungannya dengan daerah sekelilingnya", sekalipun letaknya berseberangan jalan dengan gedung Bioskop ERI yang ramai di tengah Kota Bukittinggi. (Maisir Thaib, 1996).

Sementara di kota-kota penting dataran tinggi lain, di Fort van der Capellen dan Singkarak misalnya, baru terdapat tempat penahanan kecil (kleine straften). Di Fort van der Capellen, kondisi penjara sampai akhir abad ke-19 belum tampak memadai sama sekali. Pada 1876, Belanda memang telah memperluas kawasan Fort van der Capellen, membangun kompleks bangunan yang cukup kokoh di dalam benteng itu, membangun gerbang benteng yang di halamannya terdapat dua buah meriam, yang juga dilengkapi tiga buah ruangan di sebelah kanan dan kiri gerbang, serta empat ruangan di bagian belakang berfungi sebagai kantor, bangsal militer, gudang perbekalan, dan sel tahanan atau 
penjara. Namun, kondisi penjara tersebut masih kecil saja.

Pemerintah kolonial Belanda menempatkan satu orang kepala penjara yang berasal dari pribumi yang digaji oleh Belanda sebesar $f 25$ (dua puluh lima gulden) per bulan (Staatsblad van Nederlandsch-Indie, 1876). Bangunan penjara ini terdiri dari ruang-ruang untuk kantor di bagian depan dan kamar-kamar untuk para tahanan di bagian belakang. Ruangan kantor dan ruang tahanan dipisahkan oleh pintu dari besi dan sebuah bagian lain untuk ruang penjaga. Kamar tahanan berjumlah 7 buah, yang pada masing-masing kamar terdapat jendela kecil yang ditempatkan di bawah langit-langit.

Pada periode berikutnya dari abad yang sama, laporan tahun 1894 menyebutkan bahwa penjara telah menyebar hampir ke seluruh daerah-daerah penting di Sumatera Barat (van Kesteren et al., 1907). Penjara Padang masih tetap menjadi penjara utama (centrale gevangenis), dengan daya tampung paling besar di antara penjara lainnya, 600 tahanan. Sementara penjara-penjara lain yang lebih kecil di Sumatera's Wesktust tersebar secara lebih merata, tidak hanya di kota-kota yang telah disebutkan tadi, tetapi kini juga ada di Loebeo Begaloeng (Lubuak Bagaluang), Kajoe Tanam (Kayu Tanam), Palembajan (Palembayan), Boea (Buo), dan Sidjoendjoeng (Sijunjung). Penjara-penjara tersebut dapat menampung jauh lebih kecil, antara 6 sampai 50 tahanan. Penjara Kayu Tanam misalnya hanya berkapasitas 6 orang, sementara untuk yang terbesar di luar Padang adalah Penjara Padangpanjang yang dapat menampung sampai 50 tahanan. (van Kesteren et al., 1907).

\section{Bangsal Khusus Perempuan dan Keberadaan Petugas-petugas Perempuan}

Tidak banyak sumber yang bisa dipakai untuk menjelaskan bagian ini. Beberapa catatan kolonial yang sebelumnya telah juga dirujuk nyaris tidak menyebutkan ada bangsal khusus perempuan dalam penjara-penjara di Sumatera's Westkust. Bahkan untuk penjara di Padang sekalipun, penjara terbesar untuk kawasan ini, tidak disebut-sebut ada bangsal perempuan. Padahal dalam catatan-catatan yang sama menerangkan terdapat bangsal khusus untuk orang Eropa, bangsal khusus untuk pribumi, dan bangsal khusus pekerja paksa (Van Asska, 1859).

Oleh sebab itu, dapat dikonstruksi bahwa posisi perempuan dalam dunia penjara masih diabaikan sama sekali. Asumsi ini bisa jadi benar adanya mengingat perempuan telah lama tidak menjadi bagian yang penting dalam sebuah kekuasaan patriarkis seperti kekuasaan kolonialis Belanda-sekalipun kekuasaan ini berkuasa atas sebuah daerah matriarkat seperti Minangkabau.

Dalam catatan-catatan yang memuat perdebatan ahli hukum Belanda mengenai penjara di tanah jajahannya, seperti catatan milik W. Tadama Wop (1866) dan W. E. Baron Hoevell (1870), juga tidak pernah disinggung maupun diperdebatkan tentang penjara khusus untuk perempuan. Bahkan, penanganan-penanganan untuk tahanan perempuan hampir-hampir tidak ada disebut-sebut. Perdebatan mereka lebih banyak berkisar tentang hukuman rotan (rotanslagen), makanan tahanan (voodingtarief), penanganan kesehatan, maupun pekerjaan tahanan (werkplaat) (van Voevell, 1870; W. Tadama Wop, 18667).

Beberapa catatan yang bisa disebutkan disini didapatkan dari sumbersumber pribumi, itu pun menerangkan tentang penanganan tahanan perempuan setelah memasuki abad ke-20. 
Keterangan pertama tentang keberadaan tahanan perempuan di penjarapenjara Sumatera Barat adalah tentang kejadian tahun 1908. Kejadian itu menerangkan tentang seorang perempuan separuh baya dikirim dengan kaki dan tangan terantai ke Padang. Perempuan itu datang dari dataran tinggi Minangkabau, dari nagari sebelah timur Gunung Singgalang, $11 \mathrm{~km}$ dari Tiku dan $9 \mathrm{~km}$ di barat Lubuk Basung-dari Manggopoh (NN, 1978).

Siti Manggopoh atau Siti dari Manggopoh terlibat sebuah pemberontakan melawan pemerintah kolonial Belanda. Dengan kelewang tajam ditangannya dia telah berhasil membunuh hingga 55 prajurit Belanda. Bersama suaminya dan beberapa pemuda dan pemuka nagari setempat, dia merencanakan dan terlibat langsung dalam kerusuhan melawan pemerintah, sebentuk protes atas kebijakan pajak/belasting yang diterapkan pemerintah yang dianggap terlalu menekan kawula jajahan. "Gerombolan itu", demikian dalam bahasa pejabat Belanda, mengepung benteng Belanda dalam suatu malam, dan mengirim hampir seluruh penghuninya ke neraka kematian (NN, 1978).

Namun, karena tidak terorganisir, tidak butuh waktu lama, pemberontakan itu dapat dipadamkan oleh militer Belanda. Mereka yang terlibat kemudian ditangkap dan digiring ke penjara. Siti adalah perempuan satu-satunya dalam rombongan pemberontak yang ditangkap. Pada mulanya, dia bersama suaminya melarikan diri dari Manggopoh. Namun, keduanya berhasil ditangkap.

Siti lalu dikirim ke Penjara Lubuk Basung, mendekam di sana selama 14 bulan, lalu dipindahkan ke Penjara Pariaman dan mendekam di sana selama 16 bulan. Dia sering dipindah-pindahkan, entah karena alasan apa. Pemindahan Siti berikutnya adalah ke penjara utama di Padang, tempat di mana dia menjalani hukuman terakhirnya. Di Penjara Padang, Siti mendekam selama 12 bulan, barulah kemudian dia diadili dan divonis bersalah: Siti dijatuhi hukuman 4 tahun penjara. Sisa hukumannya dijalaninya di Penjara Padang itu juga (NN, 1978).

Manggopoh Siti dari pesakitannya di penjara? Tidak banyak yang bisa diketahui, sebab tidak ada catatan apa pun yang bisa dirujuk terkait itu, baik dari sumber kolonial maupun dari sumber pribumi. Hanya terdapat keterangan yang menyebutkan bahwa di penjara, Siti mendapat "tindakan-tindakan di luar batas" yang membuat fisiknya menderita. Bagaimana persisnya "tindakan-tindakan di luar batas itu"?

Dapat dikatakan bahwa Siti mengalami beban fisik dan mental sekaligus selama dalam penjara. Bukan saja karena perlakuan di luar batas dari para petugas, tetapi juga karena Siti harus menerima ketentuan nasib bahwa dia dipisahkan dari suaminya yang tercinta. Hasyik, suami Siti, juga terlibat pemberontakan yang sama, tertangkap, lalu dibuang Belanda ke Manado. Siti ingin menemani suaminya ke pembuangan, tetapi permohonannya itu tidak diperkenankan pemerintah kolonial (NN, 1978).

Narasi selanjutnya, hampir 20-an tahun setelah Siti Manggopoh, seorang perempuan (yang dituduh terlibat huru-hara Komunis) juga digiring dari dataran tinggi Minangkabau bersama puluhan tahanan Komunis laki-laki. Upik Hitam ditangkap kerena keikutsertaannya memimpin sebuah rapat akbar di Bukittinggi-rapat akbar Partai Komunis. Dalam rapat akbar itu, perempuan yang masih muda tersebut 
tampil sebagai orator dengan mulut coklat oleh kata-kata hujatan. Dia menghujat kesewenang-wenangan kekuasaan kolonial dengan segala perangkat yang mendukungnya, juga pegawai-pegawai negeri pribumi. Dalam orasinya itu, dia mengutuk pihak penguasa, para polisi dan militer, juga mengutuk para pegawai dan pejabat pribumi yang demi kepentingannya sendiri menjilat-jilat kepada kekuasaan penjajah. Atas dasar kegiatannya itu dia kemudian ditangkap dan dipenjarakan polisi kolonial (Etek, n.d.).

Kiprah Upik Hitam dalam gerakangerakan Komunis di dataran tinggi Minangkabau memang terbilang luar biasa. Dia bukan saja seorang propagandis Komunis yang ulung seperti yang telah dikatakan di atas, tetapi dia juga seorang organisatoris sekaligus: dia memimpin organ Kaoem Iboe, (Suryadi, 2011), salah satu organ Partai Komunis yang khusus menggalang kekuatan dari kalangan perempuan. Dia sendiri berasal dari Nagari Bungo Tanjung, Padangpanjang, kota transit di dataran tinggi yang menjadi salah satu basis pertumbuhan Komunis masa itu.

Pada Desember 1926, Upik Hitam ditangkap di Batusangkar, berbilang hari sebelum Pemberontakan Silungkang meletus pada awal tahun berikutnya. Hanya kira-kira dua bulan kemudian, dia diadili di Sawahlunto. "Pengadilan Landraad Sawahloento mendjatoehkan hoekoeman pendjara 5 tahoen pada propagandist perempoean bernama Oepi' Hitam," begitu diberitakan Pandji Poestaka. (Budi, n.d.; Nordholt, 2011). Lalu entah apa sebab, hukumannya diperberat menjadi 8 tahun. "Achirnja Oepi Hitam memikoel risico tindakannja, ialah dengan menerima hoekoeman 8 tahoen lamanja jang didjalankannja disalah satoe tempat di Java," demikian laporan Sinar Soematra (Sinar Soematra, 1935).
Setelah menjalani hukumannya di Jawa, pemerintah kolonial memulangkannya ke kampung halamannya. Namun orang kampungnya tidak mau menerimanya. "Ada doea orang Datoek jang menaroeh keberatan," kata Sinar Soematra edisi yang sama. Untuk itu, dia tetap dipenjarakan pemerintah di Sumatera Barat. Ketika berita itu dipublikasikan, Upik Hitam masih mendekam [dititipkan] dalam Penjara Padang. Selama dalam penjara, tubuhnya kurus tinggal kulit pembalut tulang. Bahkan dikatakan, Upik Hitam sudah seperti setengah gila (Etek, n.d.; Sinar Soematra, 1935).

Setelah melalui masa dua tahun pemenjaraan di Penjara Padang, kisah hidupnya kemudian dibicarakan di sidang Volkstraat di Batavia. Jahja Dt. Kayo, seorang wakil Minangkabau di Volkstraat, menyampaikan sebuah pidato panjang yang pada dasarnya hendak menyampaikan: "Kenapa perempuan yang sudah tidak mungkin lagi berbahaya itu masih juga dipenjarakan? Tidakkah mamak-mamaknya sudah menjamin bahwa Upik Hitam tidak akan lagi terlibat gerakan-gerakan Komunis?" (Etek, n.d.). Tidak diketahui, bagaimana nasib Upik Hitam kemudian. Hanya didapatkan keterangan bahwa setelah namanya disebut di Volkstraat, ahli hukum Belanda mengatakan bahwa kasusnya akan dibicarakan di tingkat peradilan (Etek, n.d.).

Sejauh ini diketahui, Upik Hitam dan Siti Manggopoh, dua orang tahanan perempuan itu, tidak diperlakukan sebagaimana mestinya seorang terhukum perempuan selama mendekam di penjarapenjara di Sumatera Barat. Laporan mana pun, baik dari pihak pribumi maupun kolonial, baik tentang Siti Manggopoh maupun Upik Hitam, tidak mencatat bahwa selama mereka dipenjarakan di penjara- 
penjara Sumatera Barat, mereka ditempatkan di bangsal khusus perempuan.

Begitu pun petugas-petugas penjara yang mengurusi mereka, tidak seorang pun tercatat pernah dari kalangan perempuan. Dari sumber kolonial juga tidak ditemukan keterangan bahwa ada di antara petugas penjara di penjara-penjara di Sumatera Barat yang perempuan. Tukang masak adalah berasal dari sipir-sipir. (Marzuki, 1997; Sati, 1991), yang semuanya laki-laki (Lestariningsih, 2011). Tampaknya, pemandangan ini berlaku umum di semua penjara pemerintah kolonial di Sumatera Barat pada masa itu.

Pada akhir kekuasaan kolonial, barulah telah ada sedikit perbaikan, itu pun hanya sebatas adanya pemisahan antara blok tahanan perempuan dan laki-laki. Maisir Thaib mencatatkan tentang keadaan tahanan perempuan di Penjara Padang pada 1941, ketika penulis roman itu dipenjarakan di sana karena kasus delik pers. Dari bangsal laki-laki, Maisir Thaib dapat mendengar suara-suara perempuan di balik tembok yang berasal dari bangsal perempuan. Seorang perempuan yang ditahan di bansal itu, dalam catatan Masir, adalah seorang tukang tadah (Maisir Thaib, 1996). Berdasarkan keterangan itu, dapat dikatakan bahwa pada akhir kekuasaan kolonial dalam Penjara Padang telah terdapat bagian penjara untuk tahanan perempuan yang terpisah dari tahanan lakilaki.

Namun, jika dilihat lagi, bangsal itu berkemungkinan hanya dipisahkan sebuah tembok. Atau setidak-tidaknya tidak berjarak terlalu jauh. Hal ini karena suara dari bangsal perempuan dapat didengar di bangsal laki-laki.

Pada kondisi demikan, dapat diduga bahwa hukuman bagi tahanan perempuan tetap berlipat-lipat ganda. Seorang tahanan perempuan tidak hanya harus berhadapan dengan hukuman kurungan yang menghukum badannya, tetapi dia juga harus berhadapan dengan hukuman secara psikologis sekaligus yang mengurung jiwanya karena harus berhadapan dengan petugas-petugas yang semuanya laki-laki.

Sebagai perempuan Minangkabau yang 'tahu adat' dan dibesarkan dalam garis Islam dan matrilineal yang taat, 'berhadapan' dengan perlakuan laki-laki dari luar kaum (dalam bentuk yang halus sampai kasar) adalah sebuah beban moral yang menyiksa. Itulah yang dirasakan oleh Siti Manggopoh dan Upik Hitam bertahuntahun lamanya sebagai pesakitan.

\section{PENUTUP}

Penjara-penjara kolonial telah hadir sejak abad ke-17 di Padang dan jejaring itu semakin melebar ke dataran tinggi Minangkabau pada awal abad ke-19 seiring menguatnya kekuasaan politik kolonial teruama dipicu oleh agenda penaklukan dataran tinggi Minangkabau dalam Perang Padri.

Penjara-penjara koloial yang ada di Sumatera's Westkust tidak menyediakan bangsal khusus bagi perempuan. Hanya ada kamar titipan sebelum si terhukumperempuan dikirim ke penjara khusus perempuan di Jawa-di penjara khusus perempuan di Semarang. Begitupun semua petugas di penjara-penjara Sumatera's Westkust adalah laki-laki. Dari jajaran yang paling atas hingga tukang masak, tidak tercatat ada perempuan yang bertugas.

Ketiadaan bangsal khusus perempuan dan petugas perempuan dalam penjara-penjara kolonial di Sumatera's Westkust telah memberi hukuman yang berlipat ganda bagi seorang tahanan perempuan yakni: 1). Hukuman badan karena terkurung terali dan tembok. 2). Hukuman psikologis sekaligus karena 
harus berhadapan dengan petugas-petugas yang semuanya laki-laki.

Pada akhir-akhir kekuasaan kolonial telah ada pemisahan blok tahanan perempuan dan laki-laki. Itu ada terutama di Penjara Padang sebagai penjara utama (centrale gevangenis). Tetapi perubahan itu tampak tidak berarti banyak. Hal ini karena interaksi [suara] masih mungkin terjadi. Selain itu, petugas penjara juga masih tetap dari kalangan sipir laki-laki.

\section{REFERENSI}

Andri. (n.d.). Algemeen verslag ven het Gouveernement Sumatera's Westkust over het Jaar 1860 Eerste Afdeeling Algemeen Bestuur,: SWK, No. 127/9.

Andri. (1885). Binnenland sch BestuurNo. 237: Peta Kota Padang. Jaar.

Arsa, D. (2013). Penjara di Padang 18241942. Khazanah, VIII(15).

Arsa, D. (2017). Perempuan Memberontak: Perlawanan Perempuan Minangkabau terhadap

Kolonialisme Belanda di Sumatera Barat 1908-1942. Kafaah: Journal of Gender Studies, 7(1), 42-56.

Arsa, D. (2018). The Fall of Sawahlunto (Studi tentang Pengaruh Gejolak Ekonomi-Politik Global terhadap Perkembangan sebuah Kota Lokal, 1930-1940an). Khazanah, 49-64.

Asnan, G. (2003). Kamus Sejarah Minangkabau. Pusat Pengkajian Islam dan Minangkabau.

Budi, L. S. (n.d.). Bersekolah di Tanah Pengasingan: Boven Digul, 19271943. Jurnal Sejarah Citra Lekha, 2(2), 112-125.

Burg, C. L. (1877). Proeve van een overzicht der in Nederlandsch-Indië gepubliceerde geneeskundige boeken en der verhandelingen over geneeskundige onderwerpen, voorkomende in de tijdschriften in Nederlandsch-Indië uitgegeven tot 1 Januari 1876.

Carey, Peter, (2008). The power of prophecy. Prince Dipanagara and the end of an old order in Java, 1785-1855, Leiden: KITLV Press.

de Stuers, H. (1849). De Vestiging en Uitbreiding der Nederlanders ter Westkust van Sumatra, 1 of 2 vols. Amsterdam: PN van Kampen, Cx, 239.

Etek, A. (n.d.). Kelah Seorang Demang: Pidato Jahja Dt Kayo di Volkstraat.

Gilbert, J. (1953). A guide to historical method. Nursing Research, 2(1), 44.

Hadler, J. (2003). Rusli Amran and the rewriting of Minangkabau history. Kyoto Review of Southeast Asia.

Hasselt, A. van. (1882). Volksbeschrijving en taal: Volksbeschrijving van Midden-Sumatra. Leiden: Brill. [Midden-Sumatra: Reizen en onderzoekingen der Sumatra expeditie ....

Horton, W. B. (2016). History Unhinged: World War II and the Reshaping of Indonesian History. Unpublished $\mathrm{Ph}$. D. Dissertation. Tokyo: Graduate School of Literature, Waseda University.

Kartodirdjo, S. (1993). Pengantar sejarah Indonesia baru, sejarah pergerakan nasional. Gramedia.

Kielstra, E. B. (1980). De expeditie tegen de Pasoemahlanden.

Krisnadi, I. G. (2001). Tahanan politik Pulau Buru, 1969-1979. LP3ES.

Kuntowijoyo, M. S. (2003). Yogyakarta: PT. Tiara Wacana Yogya.

Lestariningsih, A. D. (2011). Gerwani: Kisah tapol wanita di Kamp Plantungan. PT Gramedia Pustaka Utama. 
Marzuki, H. A. (1997). Syair Perang Kamang”, dalam Anas Navis, Kajian Naskah Pemimpin ke Syurga dan Syair Perang Kamang yang Kejadian dalam Tahun 1908. Jakarta: Departemen P \& K.

Nahuijs, Brieven over Bencoolen, Padang, Het Rijk van Minangkabau, Rhiou, Singapoera en Poelo-Pinang, Breda: F. B. Hollingerus Pijpers, MDCCCXXVII

Najmi. (2013). Sejarah Kota Batu Sangkar [Thesis Master].

NN. (1978). Peringatan 70 tahun Perang Kamang Manggopoh. Jakarta; Panitia Besar Perlawanan Rakyat Minangkabau Melawan Penjajah.

Nordholt, H. S. (2011). Modernity and cultural citizenship in the Netherlands Indies: An illustrated hypothesis. Journal of Southeast Asian Studies, 42(3), 435-457.

Radjab, M. (1964). Perang Paderi di Sumatera Barat, 1803-1838. Balai Pustaka.

Rahman, A. (2019). Modernisasi Teknologi Kereta Api di Sumatera Barat Masa Hindia Belanda (1871-1933). Siddhayatra, 24(1), 17-36.

Risa, J. S. (2019). Kesusateraan Tionghoa Peranakan Dalam Majalah Doenia Baroe (1Januari-30 November 1930) [PhD Thesis]. Universitas Andalas.

ROMI, A. (2019). Ragam Peran Pewaris Kerajaan Koto Besar di Kabupaten Dharmasraya 1964-2016 [PhD Thesis]. Universitas Andalas.

Sati, T. S. (1991). Sengsara membawa nikmat (Vol. 829). Balai Pustaka.

Setiawan, A. E. (2016). Dinamika Kehidupan Tahanan Politik Pulau Buru (1965-1970). Risalah, 2(8).

Sinar Soematra. (1935).
Spierenburg, P. (1991). The Broken Spell. A Cultural and Anthropological History of Pre-Industrial Europe, New Brunswick.

Stuers, H. J. J. L. (1849). De vestiging en uitbreiding der Nederlanders ter westkust van Sumatra. PN van Kampen.

Suryadi. (2011, July 1). Penjara Muara Padang. Singgalang.

Suyono, R. P. (2005). Seks dan kekerasan pada zaman kolonial: Penelusuran kepustakaan sejarah. Gramedia Widiasarana Indonesia.

Thaib, Maisir (1996). Pengalaman Seorang Perintis Kemerdekaan Generasi Terakhir Menempuh Tujuh Penjara, Bukittinggi: Pustaka Indonesia.

Van Asska, C. J. (1859). Verslag over het Gevangeniswezen in NederlandschIndie. III(6).

van Burgst, H. G. N. (1827). Brieven over Bencoolen, Padang, het rijk van Menang-Kabau, Rhiouw, Sincapoera en Poelo-Pinang. FB Hollingerus Pijpers.

van der Meij, D. (2010). Peter Carey, The power of prophecy; Prince Dipanagara and the end of an old order in Java, 1785-1855. Leiden: KITLV Press, 2008, xx+ 970 pp.[in 2007; Verhandelingen van het Koninklijk Instituut voor Taal-, Land-en Volkenku. Wacana, 12(1), 213-218.

Van Hasselt, A. L. (1882). Ethnographische atlas van Midden-Sumatra: Met verklarenden tekst (Vol. 3). EJ Brill.

van Kesteren, C. E., van Sandick, R. A., \& de Meyier, J. E. (1907). De Indische gids (Vol. 29). JH de Bussy.

van Sandick, R. A. \& J. E. de Meyier, (1894) "Raming der ontvangsten $\mathrm{n}$ uitga ven van de Indische 
Administratie" De Indische Gis, vol. 16.

van Voevell, W. E. Baron, (1870). "Varia", in Tijdschrift voor Nederlandsch Indie, seri III edisi I Tahun ke-4

Wop, W. Tadama, (1866). Indiche Brieven van $\mathrm{Mr}$ Wop over Koloniale Hervorming: I. Proeven can WetsOntwerpen voor Radikale,
Geleidelijke en Conservatieve Hervoermers, voor Rekening van den Schrijver, $\mathrm{S}$ Gravenhage: Martinus Nijhoff.

Wilsen, F. C. (1869). Lain doeloe, lain sakarang, of voorheen en thans: Schetsen uit Oost-Indië (Vol. 1). RC Meijer. 
204 | Kafa'ah Journal, Volume 9 (2), Juli-Desember 2019, (191-204) 